\title{
Note \\ Chemistry of Ecteinascidins. Part 5: An Additional Proof of Cytotoxicity Evaluation of Ecteinascidin 770 Derivatives
}

\author{
Ryoko Toyoshima, ${ }^{a}$ Nanae Mori, ${ }^{a}$ Toshihiro Suzuki, ${ }^{a}$ Witaya Lowtangkitcharoen, ${ }^{b}$ \\ Khanit Suwanborirux, ${ }^{*, b}$ and Naoki Saito*,a \\ ${ }^{a}$ Graduate School of Pharmaceutical Sciences, Meiji Pharmaceutical University; 2-522-1 Noshio, \\ Kiyose, Tokyo 204-8588, Japan: and ${ }^{b}$ Center for Bioactive Natural Products from Marine \\ Organisms and Endophytic Fungi (BNPME), Department of Pharmacognosy and Pharmaceutical \\ Botany, Faculty of Pharmaceutical Sciences, Chulalongkorn University; Pathumwan, Bangkok 10330, \\ Thailand. \\ Received February 26, 2016; accepted March 21, 2016
}

\begin{abstract}
Eleven 2'- $N$-acyl derivatives (5a-k) were prepared from ecteinascidin 770 (Et 770: 1b) via known $18,6^{\prime}-O$-bisallyl-protected compound (3) in three steps. Their in vitro cytotoxicities were determined by measuring $\mathrm{IC}_{50}$ values against human cell lines HCT116 and DU145. 5-Isoxazolecarboylamide derivative (5i) and 4-methoxybenzoylamide derivative $(5 \mathrm{k})$ were found to be promising leads for further optimization.
\end{abstract}

Key words marine natural product; transformation; ecteinascidin; cytotoxicity; structure-activity relationship study

Ecteinascidin 743 (1a) is known by its international nonproprietary name "trabectedin" and is being marketed under the trade name "Yondelis $\left.{ }^{\circledR} ., 1-5\right)$ It was approved in September 2007 in the European Union for use in the treatment of advanced soft tissue sarcoma, and is currently being used in almost 80 countries and regions around the world, including the United States and Japan. ${ }^{6}$ However, despite its medicinal importance, there are very few structure-activity relationship $(\mathrm{SAR})^{7}$ studies owing to the meager amount of the natural product and the low chemical diversity of the biosynthetically produced derivatives. ${ }^{8,9)}$

As a result of untiring efforts to establish the medicinal chemistry of marine-derived antitumor ecteinascidin 743 (Et 743: 1a), we were able to prepare many ecteinascidin derivatives with an eye to improving cytotoxicity profiles. ${ }^{10-13)}$ To extend the scope of SARs of these fascinating marine-derived natural products, we have focused our attention on the preparation of $2^{\prime}-N$-acyl derivatives in order to investigate their cytotoxicity profiles. In this paper, we report the preparation of eleven $2^{\prime}-N$-acyl derivatives from ecteinascidin 770 (Et 770: 1b) via 18,6'-O-bisallyl-protected compound (3) in moderate yields, most of which exhibited slightly higher cytotoxicities than parent $\mathbf{1 b}$ (Fig. 1).

We have reported that $2^{\prime}-N$-(3-quinolinecarbonyl)amide $\mathbf{2 a}$, $2^{\prime}-N$-4-fluorocinnamoyl derivative $\mathbf{2 b}$, and $2^{\prime}-N-3$-pyridinecinnamyl derivative 2c were extremely potent derivatives, possessing approximately 20 - to 70 -fold higher cytotoxicity to the HCT116 human colon carcinoma cell line than $\mathbf{1 b} .^{13)}$ Those results indicated that nitrogen-containing heterocyclic amide, fluorine-substituted aromatic amide, and cinnamyl amide analogs enhanced the cytotoxicity (Table 1).

Treatment of $\mathbf{3}^{13)}$ with an acid chloride and a catalytic amount of 4-dimethylaminopyridine (DMAP) in pyridine at $60^{\circ} \mathrm{C}$ for several hours gave $2^{\prime}-N$-acyl derivatives $4 \mathbf{a}-\mathbf{d}$ in $74.6-89.8 \%$ yields (Chart 1). The reaction of $\mathbf{4 a -}-\mathbf{d}$ with tributyltin hydride, $\left(\mathrm{Ph}_{3} \mathrm{P}\right)_{2} \mathrm{PdCl}_{2}$, and $\mathrm{AcOH}$ in tetrahydrofuran (THF) at $25^{\circ} \mathrm{C}$ for $1-4 \mathrm{~h}$ gave desired amides 5a-d in $62.9-67.9 \%$ yields. The conversion of $\mathbf{3}$ into heterocyclic amide derivatives $\mathbf{5 g}-\mathbf{i}$ as well as 1-naphthalenecarbonyl amide derivative (5j) and 4-methoxybenzoyl amide derivative (5k) was achieved in moderate overall yields (45.2-72.6\%). In contrast, attempts to prepare cinnamylamide derivatives having fluorine atoms in the aromatic ring $5 \mathbf{e}$ and $\mathbf{f}$ via $4 \mathbf{e}$ and $\mathbf{f}$ gave slightly low overall yields because several minor products were generated in the two reactions steps. The structures of the synthesized compounds were established on the basis of ${ }^{1} \mathrm{H}-\mathrm{NMR},{ }^{13} \mathrm{C}-\mathrm{NMR}$, MS, and infrared (IR) spectral data along with optical rotation values (see Supplementary Materials).

The above synthesized derivatives and $\mathbf{1 b}$ were tested for in vitro cytotoxicity to two representative human solid carcinoma cell lines, HCT116 and DU145, using the 3-(4,5-dimethylthiazol-2-yl)-2,5-diphenyltetrazolium bromide (MTT) assay. Table 2 shows that the $\mathrm{IC}_{50}$ values of eleven $2^{\prime}-N$-acyl derivatives $\mathbf{5 a}-\mathbf{k}$ along with $\mathbf{1 b}$ were of nM order. In general, we found that the HCT116 cell line was more sensitive to the ecteinascidins than the DU145 cell line. Among the aromatic acyl derivatives, including cinnamylamide derivatives having fluorine atoms $\mathbf{5 a}-\mathbf{f}$, derivatives $\mathbf{5 a}-\mathbf{e}$ exhibited slightly higher cytotoxicities to HCT116 and DU145 cell lines than 1b. However, all compounds having fluorine atoms showed significantly lower cytotoxicities than known compound $\mathbf{2 b}$.

We then turned our attention to sulfur-containing heterocycles and isoxazole derivatives, such as $\mathbf{5 g}$-i, as well as 1-naph- 


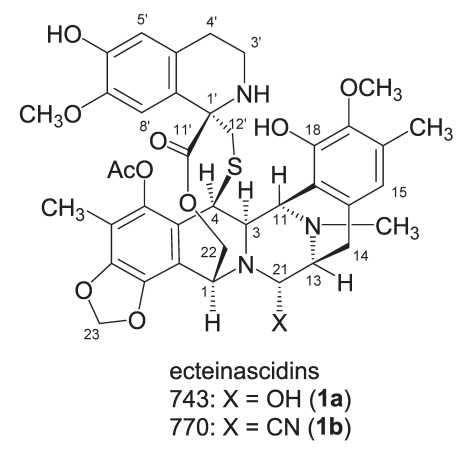<smiles>COCCOCCSC1(C(=O)OC)c2cc(OC)c(O)cc2CCN1C(=O)c1cnc2ccccc2c1</smiles><smiles>[R]C=CC(=O)N1CCc2cc(O)c(OC)cc2[C@@]1(SCCOC)C(=O)OCC</smiles>

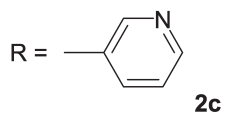

Fig. 1. Structures of Ecteinascidin Marine Natural Product and Related Analogs

Table 1. Cytotoxicities of Et 770 (1b) and Its 2'-N-Acyl Analogues to Three Carcinoma Cell Lines $\left(\mathrm{IC}_{50} \mu \mathrm{M}\right)$

\begin{tabular}{|c|c|c|c|c|c|}
\hline \multirow{2}{*}{ Entry } & \multirow{2}{*}{ Compound } & \multirow{2}{*}{$18,6^{\prime}$-O-Bisallyl derivatives of Et 770} & \multicolumn{3}{|c|}{ Cytotoxicity } \\
\hline & & & $\mathrm{HCT} 116^{a)}$ & QG56 $6^{a)}$ & DU145 ${ }^{a)}$ \\
\hline \multirow[t]{2}{*}{1} & $1 b^{b)}$ & (Ecteinascidin 770 ) & 0.71 & 1.60 & 1.60 \\
\hline & $1 b^{c)}$ & & 0.60 & 2.40 & 0.81 \\
\hline 2 & 2a & 3-Quinolinecarbonyl & 0.014 & 0.071 & 0.087 \\
\hline 3 & $2 \mathbf{b}$ & 4-Fluorocinnamoyl & 0.010 & 0.12 & 0.041 \\
\hline 4 & $2 c$ & $3-\mathrm{C}_{5} \mathrm{H}_{4} \mathrm{NCH}=\mathrm{CHCO}-$ & 0.031 & 0.068 & 0.089 \\
\hline
\end{tabular}

a) HCT116: human colon carcinoma; QG56: human lung carcinoma. DU145: human prostate carcinoma. b) For previous cytotoxicity data, see ref. 13. $c$ ) See ref. 12.

thalene amide derivative $\mathbf{5 j}$ and 4-methoxyphenyl amide $\mathbf{5 k}$. 5-Isoxazole amide 5i and 4-methoxyphenyl amide 5k exhibited significantly higher cytotoxicity to both cell lines than $\mathbf{1 b}$. However, all the compounds showed lower cytotoxicities than the previously reported compounds $\mathbf{2 a}$ and $\mathbf{c}$.

In conclusion, we found that the introduction of acyl groups at the $2^{\prime}-N$ position enhanced the cytotoxicity. $2^{\prime}-N$-Isoxazole amide derivative $\mathbf{5 i}$ and $2^{\prime}-N$-(4-methoxyphenyl)amide derivative $\mathbf{5 k}$ were the most potent derivatives, exhibiting approximately 4.9- to 6.1-fold increase in cytotoxicity to the HCT116 cell line, and 6.6- to 7.5-fold increase in cytotoxicity to the DU145 cell line, respectively, relative to $\mathbf{1 b}$.

Our findings offer new evidence that the 2 '- $N$-acyl derivatives play a novel role in the antitumor activity of ecteinascidin analogs. Further studies are needed to completely understand the molecular basis of the extraordinary cytotoxicity profiles of ecteinascidins.

\section{Experimental}

${ }^{1} \mathrm{H}$ - and ${ }^{13} \mathrm{C}-\mathrm{NMR}$ spectra were obtained on JEOL JNM-AL 300 and JEOL-JNM-ECA 500 FT NMR spectrometers. Solvent signals served as the internal standard $\left(\mathrm{CDCl}_{3}: \delta_{\mathrm{H}} 7.26 /\right.$ $\delta_{\mathrm{C}}$ 77.0). IR spectra were recorded on a Shimadzu IR Affinity-1 Fourier Transform Infrared (FT-IR) spectrophotometer. High-resolution (HR)-MS were acquired from a JEOL JMS 700 mass spectrometer with a direct inlet system operating at $70 \mathrm{eV}$. Optical rotations were measured with a Horiba SEPA-200 polarimeter. Circular dichroism (CD) measurements were conducted with a Jasco J-820 spectropolarimeter. Silica gel 60 (230-400 and 70-230 mesh) and Sephadex ${ }^{\circledR}$ LH-20 were used for column chromatography.

General Procedure for Preparation of 18, $6^{\prime}-O$-Bisallyl-2'$\mathbf{N}$-acyl Derivatives of Et $770(\mathbf{4 a}-\mathbf{k}) \quad$ Compound 3 (15.3 mg, $0.018 \mathrm{mmol})$ and DMAP $(1.1 \mathrm{mg})$ were dissolved in pyridine $(1.5 \mathrm{~mL})$, and 15 equimolar quantity of an acid chloride was added at $0^{\circ} \mathrm{C}$. The reaction mixture was heated at $60^{\circ} \mathrm{C}$ for 2 to $3 \mathrm{~h}$. After the solvent was removed in vacuo, the residue was diluted with water $(10 \mathrm{~mL})$ and extracted with chloroform $(15 \mathrm{~mL} \times 3)$. The combined extracts were washed with brine $(15 \mathrm{~mL})$, dried, and concentrated in vacuo to give a residue. The residue was purified by silica gel column chromatography using an appropriate eluent to give the corresponding purified products $(\mathbf{4 a}-\mathbf{k})$.

General Procedure for Preparation of 2 '- $\mathrm{N}$-Acyl Derivatives of Et $\mathbf{7 7 0}$ (5) Tributyltin hydride $(0.064 \mathrm{~mL}$, $0.237 \mathrm{mmol}$ ) was added dropwise over $10 \mathrm{~min}$ to a vigorously stirred solution of $\mathbf{4 a}-\mathbf{k}(14.4 \mu \mathrm{mol}),\left(\mathrm{Ph}_{3} \mathrm{P}\right)_{2} \mathrm{PdCl}_{2}(6.0 \mathrm{mg}$, $8.6 \mu \mathrm{mol})$, and $\mathrm{AcOH}(0.03 \mathrm{~mL}, 0.54 \mathrm{mmol})$ in $\mathrm{THF}(4 \mathrm{~mL})$ at $25^{\circ} \mathrm{C}$, and the reaction mixture was stirred at $25^{\circ} \mathrm{C}$ for $1-4 \mathrm{~h}$. The reaction mixture was diluted with water $(10 \mathrm{~mL})$, made alkaline with $5 \%$ aqueous $\mathrm{NaHCO}_{3}$, and extracted with chloroform $(30 \mathrm{~mL} \times 3)$. The combined extracts were washed with $5 \%$ aqueous $\mathrm{NaHCO}_{3}$, dried, and concentrated in vacuo to give a residue. The residue was purified by silica gel column chromatography using an appropriate eluent to give the corresponding purified products $(\mathbf{5 a}-\mathbf{k})$. 


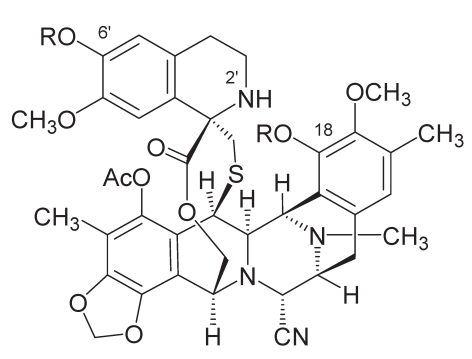

3: $\mathrm{R}=\mathrm{CH}_{2} \mathrm{CH}=\mathrm{CH}_{2}$

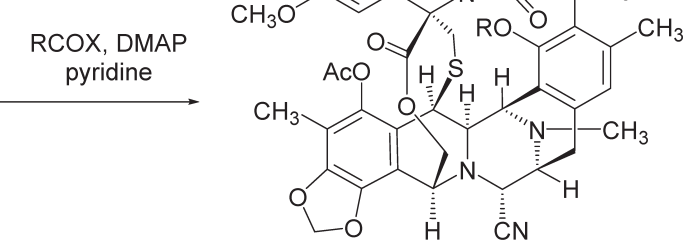

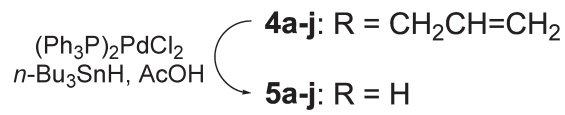<smiles>[R7]c1ccc(F)c(F)c1F</smiles>

c<smiles>[R]#Cc1cc(F)c(F)cc1F</smiles><smiles></smiles>

g<smiles>[R7]#Cc1ccc(OC)cc1</smiles>

$\mathbf{k}$

Chart 1. Preparation of $2^{\prime}-N$-Acyl Derivatives of Et 770

Table 2. Cytotoxicites of $2^{\prime}-N$-Acyl Derivatives of $\mathbf{1 b}$ to Two Carcinoma Cell Lines $\left(\mathrm{IC}_{50} \mathrm{~nm}\right)$ along with Isolation Yields

\begin{tabular}{|c|c|c|c|c|c|c|}
\hline \multirow{2}{*}{ Entry } & \multirow{2}{*}{ Compound } & \multirow{2}{*}{$2^{\prime}-N$-Acyl derivatives of Et 770} & \multicolumn{2}{|c|}{ Isolation yield (\%) } & \multicolumn{2}{|c|}{ Cytotoxicity (5) } \\
\hline & & & 4 & 5 & $\mathrm{HCT} 116^{a)}$ & $\mathrm{DU} 145^{a)}$ \\
\hline 1 & 1b & (Ecteinascidin 770) & - & - & 2.6 & 4.6 \\
\hline 2 & a & 2-Fluoro-4-methylphenyl & 74.6 & 62.9 & 1.8 & 4.5 \\
\hline 3 & b & 4-Ethoxy-2,3-difluorophenyl & 89.8 & 63.2 & 0.96 & 1.0 \\
\hline 4 & c & 2,3,4-Trifluorophenyl & 83.1 & 67.9 & 1.0 & 3.3 \\
\hline 5 & d & 2,4,5-Trifluorophenyl & 82.9 & 66.4 & 1.7 & 2.6 \\
\hline 6 & e & (2,3,4,5,6-Pentafluorophenyl)prop-2-ene & 83.4 & 21.4 & 1.7 & 3.0 \\
\hline 7 & f & (4-Trifluoromethylphenyl)prop-2-ene & 52.6 & 51.7 & 22.8 & 89.0 \\
\hline 8 & g & 2-Thiophenyl & 98.3 & 73.9 & 1.8 & 4.5 \\
\hline 9 & $\mathbf{h}$ & 3-Thiophenyl & 89.6 & 72.8 & 2.6 & 6.2 \\
\hline 10 & i & 5-Isoxazolyl & 97.6 & 52.6 & 0.42 & 0.61 \\
\hline 11 & $\mathbf{j}$ & 1-Naphthyl & 84.5 & 53.5 & 8.4 & 17.8 \\
\hline 12 & $\mathbf{k}$ & 4-Methoxyphenyl & 94.9 & 56.5 & 0.53 & 0.69 \\
\hline
\end{tabular}

a) HCT116: human colon carcinoma; DU145: human prostate carcinoma.

Cell Growth Inhibition Assay $\left(\mathrm{IC}_{50}\right)$ A single-cell suspension of each cell line $\left(2 \times 10^{3}\right.$ cells/well $)$ was added to the serially diluted test compounds in a microplate. The cells were then cultured for $4 \mathrm{~d}$. Cell growth was measured with a cell counting kit (DOJINDO, Kumamoto, Japan). IC $_{50}$ was expressed as the concentration at which cell growth was inhibited by $50 \%$ compared with the untreated control.

Acknowledgments This work was partially supported by the Japan Society for the Promotion of Science (JSPS) Grantin-Aid for Scientific Research C (No. 15K07873 to N.S.) and by the Meiji Pharmaceutical University Asia/Africa Center for Drug Discovery (MPU-AACDD to W.L.). We are also grateful to Dr. Takuo Tsukuda (Chugai Pharmaceutical Company Kamakura Research Center) for suggestions on how to obtain human solid carcinoma cell lines.

Conflict of Interest The authors declare no conflict of 
interest.

Supplementary Materials The online version of this article contains supplementary materials. ${ }^{1} \mathrm{H}-\mathrm{NMR},{ }^{13} \mathrm{C}-\mathrm{NMR}$, IR, and MS spectral data, and optical rotation values of all compounds are available.

\section{References}

1) D'Incalci M., Galmarini C. M., Mol. Cancer Ther., 9, 2157-2163 (2011).

2) Rinehart K. L., Med. Res. Rev., 20, 1-27 (2000).

3) Le V. H., Inai M., Williams R. M., Kan T., Nat. Prod. Rep., 32, 328-347 (2015)

4) Henriquez R., Faircloth G., Cuevas C., "Anticancer Agents from Natural Products," ed. by Cragg G. M., Kingston D. G., Newman D. J., Taylor \& Francis, New York, 2005, pp. 215-223.

5) Cuevas C., Francesch A., Nat. Prod. Rep., 26, 322-337 (2009).
6) “Taiho Pharma News Release.”: 〈http://www.taiho.co.jp/english/ news/20140604.html.)

7) Martinez E. J., Owa T., Schreiber S. L., Corey E. J., Proc. Natl. Acad. Sci. U.S.A., 96, 3496-3501 (1999).

8) Sakai R., Jares-Erijman E. A., Manzanares I., Silva Elipe M. V., Rinehart K. L., J. Am. Chem. Soc., 118, 9017-9023 (1996).

9) Menchaca R., Martinez V., Rodriguez A., Rodriguez N., Flores M., Gallego P., Manzanares I., Cuevas C., J. Org. Chem., 68, 88598866 (2003).

10) Suwanborirux K., Charupant K., Amnuoypol S., Pummangura S., Kubo A., Saito N., J. Nat. Prod., 65, 935-937 (2002).

11) Puthongking P., Patarapanich C., Amnuoypol S., Suwanborirux K., Kubo A., Saito N., Chem. Pharm. Bull., 54, 1010-1016 (2006).

12) Saktrakulkla P., Toriumi S., Tsujimoto M., Patarapanich C., Suwanborirux K., Saito N., Bioorg. Med. Chem., 19, 4421-4436 (2011).

13) Tsujimoto M., Lowtangkitcharoen W., Mori N., Pangkruang W., Puthongking P., Suwanborirux K., Saito N., Chem. Pharm. Bull., 61, 1052-1064 (2013). 